\title{
Phenomenon of Indian Ethnic Business Communication in Bandung City, West Java
}

\author{
(Phenomenology Study on Indian Ethnic Entrepreneurs in Bandung)
}

\author{
Nisrina* \\ Master of Communication Science \\ Universitas Islam Bandung \\ Bandung, Indonesia \\ *Nisrina14054@gmail.com
}

\author{
Nurrahmawati \\ Faculty of Communication \\ Universitas Islam Bandung \\ Bandung, Indonesia \\ Nurrahmawati@unisba.ac.id
}

\begin{abstract}
There are so many business activities in Bandung City, one of that business is textile business which is famous for being managed by Indian ethnic. This study aims to analyze the motives and meanings of Indian ethnic entrepreneurs in running business communication. This study used a qualitative research method with the phenomenological approach from Alfred Schutz. The theory used is the symbolic interaction theory from George Herbert Mead. The results of this study are the motives possessed by Indian ethnic entrepreneurs in conducting business communication, namely family motives, economic motives, and ego motives. The meaning that Indian ethnic entrepreneurs have from business communication activities are information exchange, cultural adjustment, and nonverbal communication skills. This phenomenon becomes interesting. Because Indian ethnic entrepreneurs who have met with buyers of different cultures for years, still have language barriers in running this textile business.
\end{abstract}

Keywords-business communication, indian ethnic, meanings, motives, phenomenology

\section{INTRODUCTION}

Various types of business, ethnicity, and trading methods can be found in the city of Bandung. Likewise, Indian ethnic entrepreneurs who are quite easy to find in the city of Bandung. The author is interested in raising this phenomenon, because many Indian ethnic entrepreneurs also work as entrepreneurs, especially in the textile business. This Indian ethnic entrepreneur is not inferior to the Arab or Chinese ethnic who are synonymous with business activities. Their trades are in the fields of convection (textiles), optics, watches, and spices. In the city of Bandung, this can be found in the area around Jalan Otto Iskandardinata, Jalan ABC, and other areas. Businesses run by ethnic Indians in Bandung City are quite prominent in the midst of the domination of Chinese ethnic businesses which are famous for their trading activities. one of the identities of Indian ethnic businesses is the textile business.

Inter-ethnic communication occurs when migration from different ethnicities to areas that have different ethnicities.
When these migrants intend to settle in the area, they need to adapt to the area, both in terms of customs, language, culture, and others. In the adaptation process, difficulties will arise, both cognitive and affective [1].

As well as meeting natives with other nations through trade routes. The history goes back to when traders from Gujarat, India, came carrying beautiful fabrics through the north coast of Java in the 14th century [2].

The most common communication difficulties are miscommunication and misperception. Not only between individuals with different cultural backgrounds, but also humans as social creatures in general. Even between buyers and sellers, there can be miscommunication and misperception, because there are differences in motivation, perceptions, and interests between the seller and the buyer. Buyers want to buy as cheaply as possible, while sellers want to make the most of their profit and get a sustainable deal.

Besides being known for its culinary tourism, the city of Bandung is another mainstay of products, including fashion. Consumers from Jakarta, even our neighboring countries such as Malaysia and Brunei Darussalam are interested in shopping for fashion in Bandung [3].

The interest of tourists to shop in the city of Bandung is also supported by the ease of access to the city of Bandung, starting from direct flights at Husein Sastranegara Airport, railways, and other transportation access. This is also one of the motives of Indian ethnic entrepreneurs in running their business in Bandung.

\section{MethodS}

This study used qualitative research methods assisted by the symbolic interaction theory of George Herbert Mead. To answer this research question, the author uses a scalpel from Alfred Schutz's glasses in a phenomenological approach, namely meaning and motive. Data collection techniques in this study by conducting interviews, observation, and documentation. 
The subjects of this study were three business communication actors, namely textile entrepreneurs in the city of Bandung with Indian ethnicity from three different shops. The entrepreneur is an Indonesian citizen of Indian descent, domiciled in the city of Bandung, has been in business for five years, and has experience interacting with buyers directly in conducting business negotiations.

\section{RESULTS AND DISCUSSION}

Motive is divided into two categories, namely because motive and in order to motive. Because the motive possessed by Indian ethnic entrepreneurs has a correlation with the in order to motive they have. The results identified that there are three motives that encourage Indian ethnic entrepreneurs to run a business, especially in the textile sector, namely family motives, economic motives, and ego motives (Figure 1).



Fig. 1. Motives of business communication of indian ethnic entrepreneur.

Family motive means the reason that drives them to run this textile business is running a family business that has been passed down from generation to generation. Indian society highly values traditional kinship values, so returning to the family and continuing the family business is not a burden to the informant of the Indian Ethnic entrepreneur. This is because traditional Indian culture has a relatively strict social hierarchy. From an early age, children are taught about their roles and positions in society [4].

The economic motive means that Indian ethnic entrepreneurs want their business to continue to compete and generate lots of profits. The economic motive in which there is a desire to increase sales, maintain relationships, meet buyer needs, and get buyer satisfaction is a manifestation of the strong desire of Indian ethnic entrepreneurs to improve their business. In the ego motive, Indian ethnic entrepreneurs prove their capabilities as textile businessmen. This is because the informant proved to get an award from his extended family for his capability in running the textile business, as well as the capability of the Indian people in general who can be successful with their own business according to Swadesi's teachings.

The meaning that ethnic Indian entrepreneurs have from business communication activities are information exchange, cultural adaptation, and nonverbal communication skills (Figure 2).

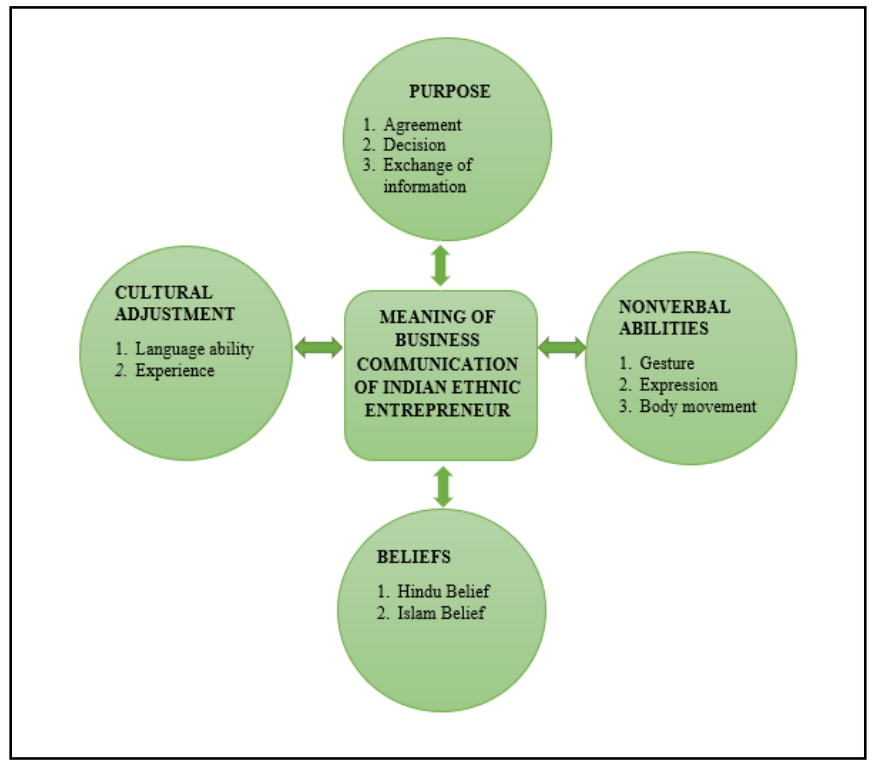

Fig. 2. Meaning of business communication of indian ethnic entrepreneur.

Meaning comes from one's social interactions with each other and that meaning is treated or changed through the interpretive process that people use in interpreting a social phenomenon [5].

The meaning is meaningless, until it is interpretively constructed by individuals through a process of interaction, to create a meaning that can be mutually agreed upon [6].

Indian ethnic entrepreneurs interpret business communication as an exchange of information about a business with the aim of getting an agreement between communication actors. Cultural adaptation means that Indian ethnic entrepreneurs start business communication by looking at the country of origin of their buyers first, then adjusting to the language used and anticipating the different ways of communicating that might occur. Nonverbal communication skills are defined as communication that involves limbs, which includes facial expressions, body movements, which have their own meaning to mark a particular purpose.

This phenomenon becomes interesting. Because Indian ethnic entrepreneurs who have met buyers of different cultures for years, still find language barriers in running this textile business. In addition, even though the three informants are of Indian ethnicity, they have different ways of conducting business communication, including the impression they appear as a shop owner and the boss of their employees.

There are three Indian ethnic entrepreneurs who became informants in this study, two of whom are Hindus and one is Muslim. This religious aspect is also interesting to discuss, because in addition to interpreting business communication 
activities as a way to increase business profits and help consumers, there is a belief they have according to their beliefs.

Hindus have belief in running a business which is stated in a verse in the Veda Regs which reads:

\section{"Mahas ca rayo revatas krdhi ah"}

"Ya, Hyang Widhi, grant us abundant wealth"

(Reg Veda X.22.15)

One of the verses from the Hindu holy book explains that Hindus are allowed to live richly with abundant wealth. However, this wealth is not to be enjoyed alone, but must be useful for others. In the Yajur Veda it is written as follows:

"Suviryasya rayasposasya daditarah syama"

"Let's give money for the welfare of others who need it"

(Yajurveda VI.14)

In addition, the benefits of Hindu wealth for others can be realized by running a business. The following verse is the basis for it:

\section{"Murdhanam raya arabhe"}

"We get money so we can grow our businesses"

(Reg. Veda I.24.5)

By developing business, Hindu wealth can benefit many people. People who use the products / services they produce are examples of people who have benefited. Other examples are suppliers / suppliers and the employees they hire. The more their business grew, the more people would benefit from their wealth. With this belief, Indian ethnic entrepreneurs who are Hindus conduct business communication as well as possible. Because, they must provide benefits for others, namely customers and employees.

Not only in Hindu beliefs, in Islam it has explicitly legalized buying and selling or trading activities and prohibited usury. In fact, before Allah SWT was appointed as a Prophet, the Prophet Muhammad SAW was an honest merchant. In the Al-Qur'an, it is recorded that there are a number of verses about buying and selling. These verses include: "O you who believe, spend (in the way of Allah) a portion of the sustenance that We have given you before the day comes, on that day there is no buying and selling and no more syafa'at. And those who disbelieve are the wrongdoers." (Surah Al-Baqarah: 254).

“... even though Allah has made buying and selling legal and forbidden usury, " (Surah Al-Baqarah: 275). In the letter at-Taubah verse 111 also contains the word buying and selling," Verily Allah has bought from the believers themselves and their property by giving them heaven. They fight in the way of Allah; then they either kill or get killed. (It has become) the true promise of Allah in the Torah, the Bible and the Qur'an.
And who can keep his promise (other than) than Allah? So be happy with the buying and selling that you have done, and that is a great victory."

What has been exemplified by the Prophet Muhammad is a good thing when followed by Muslims, because it has been proven good and there is no futility in it. So, if Rasulullah SAW has exemplified trading in his time, and Allah has also called on His people to trade in His verses, then Muslims will carry out their trades with due regard to the rules and limitations.

\section{CONCLUSION}

The conclusion of this study is that the phenomenon of Indian ethnic business communication that occurs in Bandung is inseparable from the historical role, namely the meeting between natives and Indian ethnicities through trade routes. These Indian ethnic entrepreneurs have motives and meanings in carrying out business communications in their business activities. Based on the results of this study, there are still language barriers in business communication activities, even though the communication actors (Indian ethnic entrepreneurs) have been running this business for years. Indian ethnic entrepreneurs are also adaptive in conducting business communication activities. They adjust their position with the interlocutor, their communication style can be different depending on who they are talking to. Apart from worldly backgrounds, Indian ethnic entrepreneurs also have their respective beliefs which they believe is one of the religious elements in running their business.

\section{ACKNOWLEDGMENT}

Thank you to: Rector of Bandung Islamic University, Chair of the Institute for Research and Community Service, Director of Postgraduate Programs.

\section{REFERENCES}

[1] H. Heryadi and H. Silvana, "Komunikasi Antarbudaya Dalam Masyarakat Multikultur,” J. Kaji. Komun., vol. 1, no. 1, pp. 95-108, 2013.

[2] Okelifestyle, "Menyatukan Dua Budaya," 2009.

[3] H. Hasim, "Pola Komunikasi Bisnis Etnis Sunda Di Bandung," ENSAINS J., vol. 1, no. 1, pp. 36-43, 2018.

[4] E.M. Makar, An merican's Guide to Doing Business in India. Simon and Schuster, 2007.

[5] T. Wiwitan and N. Yulianita, "The Meaning Construction of Public Relations Marketing of Islamic Private Higher Education PR," J Messenger, vol. 10, no. 2, pp. 135-143, 2018.

[6] Y. Yuniati, A. Yuningsih, and N. Nurahmawati, "Konsep Diri Remaja Dalam Komunikasi Sosial Melalui 'Smartphone,"” Mimb. J. Sos. dan Pembang., vol. 31, no. 2, pp. 439-450, 2015. 